\title{
neofilolog
}

\author{
Czasopismo Polskiego Towarzystwa Neofilologicznego \\ ISSN 1429-2173, 2018, NR 51/1, 29-41 \\ http://dx.doi.org/10.14746/n.2018.51.1.3 \\ http://poltowneo.org/
}

\begin{abstract}
Krystyna Droździat-Szelest
Uniwersytet im. Adama Mickiewicza w Poznaniu, Wydział Anglistyki

https://orcid.org/0000-0003-2376-0662

krysiad@wa.amu.edu.pl
\end{abstract}

\section{INNOWACYJNOŚĆ W EDUKACJI JĘZYKOWEJ A PROFESJONALIZM NAUCZYCIELA}

\begin{abstract}
Innovation in language education vs. teacher professionalism
Innovation in language education, just as in any other discipline, is connected with changes whose primary goal is to make the process of language learning/language teaching more efficient. Examples of such innovations include, for instance, task based instruction, computer assisted language learning or the use of portfolio as a means of assessment. Innovation implies a new, qualitatively different perception of the language learning/ language teaching process, roles of teachers and learners, use of materials etc., hence it is believed to constitute a challenge for language teachers and their professionalism.

The present article is an attempt to answer the question whether and to what extent the language teaching profession is actually prepared to deal with innovation.
\end{abstract}

Keywords: innovation, teacher professionalism

Słowa kluczowe: innowacja, działania innowacyjne, profesjonalizm nauczyciela

\section{Wprowadzenie}

Innowacyjność w edukacji językowej, tak jak w każdej innej dziedzinie, nieodłącznie wiąże się ze zmianami, których nadrzędnym celem jest usprawnienie/optymalizacja procesu nauczania języka przez wprowadzenie nowatorskich rozwiązań. Jako przykłady tak postrzeganej innowacyjności można podać 
np. wprowadzenie nauczania zadaniowego, wykorzystanie technologii informacyjnych czy zastosowanie portfolio w procesie oceniania ucznia. Za przejaw innowacyjności można również uznać ekspansję języka angielskiego w nowych kontekstach nauczania, jak np. nauczanie przedszkolne czy coraz popularniejsze zintegrowane nauczanie przedmiotowo-językowe (ang. Content and Language Integrated Learning - CLIL).

Niewątpliwie innowacyjność niesie ze sobą nowe, jakościowo inne postrzeganie procesu nauczania czy też roli nauczyciela i ucznia w tym procesie, a co za tym idzie, stanowi ona swoisty rodzaj wyzwania dla profesjonalizmu nauczycieli. Stąd też celem niniejszego artykułu jest spojrzenie na innowacyjność w edukacji językowej z perspektywy nauczycieli, którzy w dużym stopniu będą odpowiedzialni za powodzenie wprowadzanych zmian.

Wstępem do rozważań na temat innowacyjności mogą i powinny być zmiany, jakie nastąpiły w edukacji na przestrzeni ostatnich lat XXI wieku. W jeszcze nie tak odległej przeszłości głównym zadaniem edukacji było wyposażenie uczniów w wiedzę, która miała wystarczyć im na całe życie. Dziś głównym zadaniem szkoły jest przygotowanie uczniów do funkcjonowania w gwałtownie zmieniającym się świecie, w świecie zmian ekonomicznych i społecznych, w którym ważna będzie umiejętność np. przystosowania się do zawodów, które jeszcze nie powstały, stosowania technologii, których jeszcze nie wynaleziono, czy też rozwiązywania niewyobrażalnych/nieprzewidywalnych aktualnie problemów społecznych. Istotna stanie się nie tyle posiadana wiedza, która już dziś jest powszechnie i szybko dostępna, ile umiejętność oceny jej rzetelności i przydatności w konkretnej sytuacji.

Dlatego też współczesna edukacja, przynajmniej w teorii, koncentruje się na osiąganiu takich celów jak:

a) stymulowanie/rozwijanie procesów myślowych - kreatywności, krytycznego myślenia, umiejętności rozwiązywania problemów i podejmowania decyzji;

b) świadomość możliwości stosowania różnych form pracy, w tym umiejętności komunikacji oraz współpracy w grupie;

c) wyposażenie w wiedzę o dostępnych narzędziach pracy, z uwzględnieniem nie tylko umiejętności wykorzystania technologii, ale też rozwijania świadomości odnośnie do jej potencjału w nowych sytuacjach;

d) rozwijanie sprawności/umiejętności społecznych i emocjonalnych, które ułatwiają funkcjonowanie w grupie, w tym wspólne działania (odwaga, prawość, ciekawość, umiejętności przywódcze, odporność, empatia; por. Schleicher, 2016). 


\section{Innowacja w edukacji: definicje, ograniczenia, uwarunkowania}

Sformułowane powyżej cele nie pozostawiają wątpliwości, że edukacja, jaką znamy, nie zawsze jest w stanie sprostać takim wymaganiom i że niezbędne stają się kolejne zmiany, mające na celu dostosowanie edukacji do potrzeb szybko zmieniającej się rzeczywistości. Innymi słowy, edukacja wymaga wprowadzania nowatorskich rozwiązań czy też innowacyjności. Czym jest zatem innowacja? Jedna z definicji określa innowację jako pomysł, zamierzenie lub też działanie praktyczne, postrzegane jako nowatorskie przez jednostkę lub jednostki; ukierunkowane na postęp, czy też usprawnienie, w odniesieniu do osiągania oczekiwanych celów (por. Nicholls, 1983, za Markee, 2001: 120). Markee (ibidem) modyfikuje tę definicję na potrzeby edukacji językowej. W jego rozumieniu innowacja to propozycja wprowadzenia zmian jakościowych w podejściu do nauczania, materiałów dydaktycznych czy wreszcie wartości; zmiany te postrzegane są jako nowatorskie przez jednostki tworzące system edukacyjny.

Innymi słowy, działania innowacyjne mają charakter planowany oraz celowy i dotyczą zmian czy też rozwiązań systemowych. Sergeant (2001: 242) postrzega innowacyjność w nauczaniu języka drugiego jako przemyślaną zmianę w filozofii nauczania/uczenia się, wynikającą z bezpośredniego doświadczenia, badań, czy też innych zabiegów, która przekłada się na stosowanie działań pedagogicznych prowadzących do uzyskiwania lepszych wyników w procesie nauczania języka.

Zawadzka (2004: 281) przytacza definicję Smak (1997: 61), według której innowacja to „twórcze rozwiązanie praktyczno-pedagogiczne polegające na świadomym wprowadzeniu do zastanego wycinka rzeczywistości pedagogicznej novum, które warunkuje uzyskanie lepszych wyników w relacji do dotychczasowych sposobów, środków, form i nakładu sił". Jak wyjaśnia Zawadzka (ibidem), , ,innowacja jest więc rozumiana jako pewna zaplanowana interwencja, która zakłada zmiany w treści i sposobach działania lub w strukturze organizacyjnej i może pociągnąć za sobą inną nieplanowaną zmianę".

Innowacja prawie zawsze wynika z rozczarowania istniejącymi rozwiązaniami oraz z przeświadczenia, że wprowadzenie zmian doprowadzi do osiągnięcia lepszych rezultatów. Pomimo tego, że, zasadniczo, celem zmian jest poprawienie sytuacji, to jednak należy sobie zdawać sprawę, iż innowacja nie zawsze oznacza zmiany na lepsze w porównaniu z poprzednimi praktykami. Co więcej, innowacja może być szkodliwa i nie należy jej wprowadzać za wszelką cenę, bez rozważenia ewentualnego ryzyka. Nie wszystkie działania innowacyjne zwieńczone są sukcesem, co więcej, mogą być one ryzykowne, a ich wprowadzanie związane z wieloma trudnościami. Jak podaje Markee (1997: 6), powołując się na dostępne dane, około $75 \%$ wszystkich innowacji nie wytrzymuje 
testu czasu; a ponadto wraz z jego upływem zmienia się postrzeganie innowacyjności, która przestaje być „nowością”, a staje się oczywista i powszechna, w związku z czym przestaje wzbudzać emocje.

Inicjatorzy działań innowacyjnych powinni zdawać sobie sprawę z szeregu ograniczeń, którym podlegają takie działania i które mają źródła społeczne, kulturowe, ideologiczne, historyczne, polityczne, administracyjne, instytucjonalne itp. Carless (2013) wyróżnia trzy kategorie takich ograniczeń: w odniesieniu do nauczyciela, w odniesieniu do systemu oraz $w$ odniesieniu do instytucji, w której wprowadzana jest/ma być innowacja. Każda z tych kategorii związana jest z określonymi konsekwencjami.

W przypadku nauczycieli brak zrozumienia z ich strony konieczności wprowadzenia innowacji oraz jej akceptacji z reguły skazuje takie przedsięwzięcie na porażkę. To samo może dotyczyć sytuacji, w której wprowadzane zmiany nie są zgodne z systemem wartości/przekonań nauczyciela. Przykładem może tu być nauczanie komunikacyjne, w którym nie zwraca się uwagi na popełniane błędy językowe, jeśli został osiągnięty cel komunikacyjny. Nauczyciele mogą też negować celowość wprowadzania samooceny (ich zdaniem uczeń nie posiada bowiem odpowiedniej wiedzy/narzędzi), wykorzystania technologii informacyjnych na lekcji (odwracają uwagę ucznia) itp. Emocjonalne przywiązanie do stosowanych praktyk, postrzeganie zmian jako zagrożenia (np. dla autorytetu nauczyciela) czy wreszcie negatywne nastawienie związane choćby z dodatkowym wysiłkiem również nie sprzyjają działaniom innowacyjnym (por. Carless, 2013).

Ograniczenia systemowe wynikają z braku komunikacji i wzajemnego zaufania między inicjatorami zmian i wykonawcami. Ma to miejsce w przypadku, gdy zbyt mało uwagi poświęca się samej procedurze wprowadzania zmian, kosztem skupiania się na detalach. Brak odpowiednich środków wspierających (np. środków finansowych, sprzętu), niewystarczające przygotowanie nauczycieli i brak koniecznego wsparcia czy wreszcie nieumiejętność powiązania teorii z realiami (np. różnice kulturowe w przypadku promowania autonomii ucznia) to kolejne czynniki prowadzące do takich ograniczeń.

Istotne będą również ograniczenia w odniesieniu do instytucji (szkoły), w której planowane jest wprowadzenie innowacji. Brak wsparcia dla zmian, konserwatywne środowisko wewnątrzszkolne, brak poparcia i zrozumienia ze strony władz, brak odpowiedniej infrastruktury, problemy z dostosowaniem się uczniów do nowych nauczycieli itp. nie są dobrymi prognostykami dla działań innowacyjnych.

W tym kontekście warto odnieść się do przydatnego rozróżnienia między tzw. innowacją zasadniczą (ang. primary innovation) a innowacją drugorzędną (ang. secondary innovation), wprowadzonego przez Markee (1997). Pierwsza obejmuje zmiany np. metod i materiałów nauczania, druga zaś dotyczy 
zmian organizacyjnych, które wspierają innowację zasadniczą (mogą odpowiadać za brak powodzenia we wprowadzaniu innowacji, np. podział klas na grupy, ograniczona liczba godzin przeznaczonych na naukę języka).

Różne gremia decyzyjne - rządy, instytucje, dyrektorzy szkół, nauczyciele - starają się, aby proces edukacji był jak najbardziej efektywny i właśnie temu ma służyć wprowadzanie nowatorskich rozwiązań. Jednak aby proces wprowadzania innowacji został uwieńczony powodzeniem, musi ona spełniać pewne określone warunki, wśród których należy wymienić:

- relatywne korzyści dla osób wprowadzających nowatorskie rozwiązania (zalety, zyski) (ang. relative advantage) - np. lepsze wykorzystanie czasu na lekcji, dostępność materiałów, zaangażowanie uczniów, większa samodzielność;

- kompatybilność innowacji z poprzednimi rozwiązaniami (różnice - podobieństwa) (ang. compatibility) - np. na ile wprowadzane rozwiązania mogą bazować na tych stosowanych dotychczas;

- stopień trudności - jak trudno zrozumieć lub wprowadzić nowe rozwiązania (ang. complexity);

- jak łatwo można sprawdzić działanie innowacji (na etapach jej wprowadzania) (ang. trialability);

- obserwowalność - czy efekty działania są widoczne i w jakim stopniu! (ang. observability) (por. Markee, 2001: 123).

$Z$ reguły działania innowacyjne, które są postrzegane jako relatywnie przynoszące więcej korzyści, bardziej kompatybilne, nietrudne do wprowadzenia i mniej skomplikowane, są łatwiej i szybciej akceptowane i wprowadzane w danym kontekście, przy czym powodzenie innowacji jest oceniane przez pryzmat sukcesu osiągniętego w uczeniu się, tzn. mierzone przyrostem wiedzy i/lub umiejętności w porównaniu ze stanem sprzed wprowadzenia innowacji. Miarą powodzenia innowacji będą także stopień, w jakim nauczyciele stosują nowe rozwiązania, tzn. materiały, metody, podejścia, a także wpływ wywierany na wyznawane przez nich wartości pedagogiczne.

W trosce o powodzenie innowacji jej inicjatorzy powinni zadać sobie następujące pytania:

- $\quad$ Czy nowatorskie rozwiązania mają wsparcie ze strony innowacji drugorzędnych (zmiany organizacyjne)?

- Czy zabezpieczone zostały odpowiednie ramy czasowe i czy zapewniono uzyskanie pozytywnych rezultatów w okresie wprowadzania innowacji (znaczenie motywacyjne - pozytywne nastawienie)?

- Czy nauczyciele od początku uczestniczą w projekcie (co zapewnia pozytywny oddźwięk)? 
- Czy innowacja przyczynia się do rozwoju profesjonalnego i czy wsparcie dla takiego rozwoju jest wbudowane w projekt (instytucjonalne!)?

- Czy innowacja odpowiada założeniom kontekstu edukacyjnego oraz uwarunkowaniom kulturowym i czy nie promuje wartości sprzecznych $z$ istniejącymi?

- Czy w projekt wbudowane są strategie rozwiązywania problemów, a także strategie zmian w zarządzaniu, umożliwiające radzenie sobie z pojawiającymi się wyzwaniami? (por. Carless, 2013).

Należy również uwzględnić fakt, że innowacje mają wpływ nie tylko na nauczycieli i uczniów, ale też na rodziców, edukatorów, lokalne społeczności czy nawet polityków, a rezultaty wprowadzanych działań innowacyjnych nie będą widoczne z dnia na dzień, stąd tak ważne jest m.in. propagowanie przykładów udanych innowacji - tzw. dobrych praktyk.

\section{Innowacyjność w edukacji językowej}

W ostatnich latach byliśmy świadkami wielu innowacji w nauczaniu języków obcych, które wynikały ze zmian zachodzących zarówno w tej dyscyplinie, jak i w dyscyplinach jej pokrewnych. Widdowson (2004: 353) wskazuje dwa istotne czynniki leżące u podstaw takich zmian: pierwszy z nich to postrzeganie, a w konsekwencji określanie celów nauczania, tzn. rodzaju wiedzy językowej i/lub umiejętności, które uczący się chcieliby/powinni opanować w trakcie kursu/procesu nauczania. Drugi czynnik związany jest z procesem nauczania/uczenia się i dotyczy odpowiedzi na pytanie, jakiego rodzaju działania nauczyciela/ucznia są najbardziej pożądane, aby możliwe było osiągnięcie założonych celów.

Widdowson (2004) postrzega historię nauczania języka (angielskiego) jako sekwencję następujących po sobie różnych wizji celów nauczania oraz procedur osiągania tych celów. Istotne jest, w jaki sposób cele i procedury ich osiągania są ze sobą powiązane, co znajduje odzwierciedlenie w planowaniu procesu nauczania języka. W kontekście edukacji językowej, przekładającej się np. na programy nauczania, oznacza to skupienie się na wybranych aspektach języka (np. gramatyka, leksyka, formy vs. funkcje językowe, sprawności językowe, język specjalistyczny). W historii nauczania języków obcych widoczne są zmiany w podejściu do języka: od postrzegania go jako systemu będącego przedmiotem badań (przyswajanie wiedzy językowej jako cel sam w sobie) do uświadomienia sobie, że uczenie się języka polega na nabywaniu umiejętności używania go w konkretnych sytuacjach, a posiadanie wiedzy o języku jest postrzegane jako środek do osiągnięcia tego celu. Dla przykładu, na przestrzeni ostatnich lat (od lat 70. ubiegłego wieku) podkreśla się komunikacyjną funkcję języka i zwraca uwagę na jego funkcjonowanie w różnych kontekstach. Tak więc 
w odniesieniu do celów nauczania/uczenia się można zauważyć, jakim zmianom podlegało - w zależności od obowiązujących aktualnie teorii językowych (opis języka) - np. postrzeganie biegłości językowej (ang. language proficiency) i związanych z nią umiejętności ucznia.

Stosowane procedury nauczania związane są z procesem uczenia się języka i, jak wiadomo, różne teorie proponowały w tym względzie różne rozwiązania, które skutkowały stosowaniem określonych metod i technik nauczania, spełniających w danym okresie kryteria innowacyjności. Z punktu widzenia nauczyciela, poparte dowodami stwierdzenie, że zapewnienie określonych warunków w klasie sprzyja procesowi uczenia się, czy też znacznie przyspiesza/usprawnia ten proces, jest wystarczającą zachętą do wprowadzenia określonych rozwiązań. Różne podejścia do nauczania języka różnią się co do sposobu definiowania, jakie cechy uczniów powinny być akcentowane/wydobywane w procesie uczenia się na określonym kursie czy też w jaki sposób powinien przebiegać proces uczenia się/nauczania. Z reguły założenia każdego z tych podejść opisywane są w kategoriach teorii języka (definiowanie celów uczenia się) oraz teorii uczenia się (opis procesu - metod i technik nauczania). Jeśli więc mówimy o innowacjach w edukacji językowej, niewątpliwie punktem wyjścia będzie określenie celów nauczania/uczenia się języka oraz związanych z nimi procedur osiągania tych celów.

Istotne w procesie wprowadzania zmian w edukacji językowej są także czynniki sytuacyjne, w szczególności kulturowe, np. wartości pedagogiczne. W związku z tym takie rozwiązania, jak nauczanie skoncentrowane na uczniu, podejście komunikacyjne czy idea treningu ucznia w kierunku autonomii mogą być obce kulturowo bądź też niepopularne w danym kontekście edukacyjnym. A zatem ważne jest, aby wprowadzane rozwiązania innowacyjne były dostosowane do lokalnego kontekstu edukacyjnego oraz respektowały ogólnie przyjęte zasady.

Sprostanie wyzwaniom współczesnego świata wymaga nowych, czy wręcz nowatorskich, rozwiązań w edukacji, w tym w edukacji językowej. Rozwiązania takie, zwłaszcza w XXI wieku, w dobie globalizacji, utożsamiane są przede wszystkim z wykorzystaniem technologii informacyjno-komunikacyjnej (głównie komputera i Internetu), nazywanej technologią społeczeństwa informacyjnego. Chociaż jej podstawowym zadaniem jest zapewnienie nieograniczonego dostępu do wiedzy, to jednak za równie istotne można uznać promowanie nauczania opartego na aktywnym zaangażowaniu ucznia w proces zdobywania wiedzy. Zaangażowanie to ma miejsce m.in. poprzez:

- umożliwienie dostępu do uczenia się przez doświadczenie (np. symulacje, prezentacje);

- $\quad$ promowanie nauczania opartego na projektach i poszukiwaniu;

- $\quad$ dostęp do zadań praktycznych, wymagających współpracy; 
- ocenianie kształtujące („formujące”) w realnym czasie, tu i teraz (por. Schleicher, 2016).

Wykorzystanie technologii informacyjno-komunikacyjnych w procesie nauczania języka daje nauczycielowi praktycznie nieograniczone możliwości. Kiedy nauczyciel decyduje się prowadzić lekcje języka z wykorzystaniem TIK, ma do dyspozycji m.in. następujące narzędzia: platformy cyfrowe (ang. digital platforms); gry komputerowe; światy wirtualne; komunikację online; materiały autentyczne online; korpusy językowe, tablice interaktywne; urządzenia mobilne (smartfony, tablety, laptopy z dostępem do sieci, czytniki); czy też e-podręczniki. Wszystkie one zapewniają autentyczny kontakt z językiem, a jednocześnie oferują bogactwo form kontaktu. Dla przykładu, platformy cyfrowe zapewniają możliwość skorzystania z wielu scenariuszy zajęć, proponują różne opcje rozwiązywania problemów czy wreszcie motywują (bądź zmuszają) uczących się do samodzielności w zdobywaniu wiedzy. Gry komputerowe, aczkolwiek postrzegane negatywnie przez wielu nauczycieli, posiadają niezaprzeczalne walory kształcące - rozwijają spostrzegawczość, koncentrację, refleks, wyobraźnię przestrzenną oraz kreatywność. Gry edukacyjne sprzyjają edukacji uczestniczącej, stymulują procesy poznawcze, przez co przyczyniają się do rozwoju ucznia na wielu płaszczyznach. Komunikacja online pozwala na używanie języka w autentycznym kontekście, a wreszcie aplikacje tworzone np. na smartfony motywują do uczenia się i powtarzania słownictwa w atrakcyjny, zróżnicowany sposób.

Stosowanie przez nauczycieli nowych, innowacyjnych rozwiązań, wymienionych powyżej, może przyczynić się do wzbogacenia i uatrakcyjnienia ich warsztatu pracy, choć z drugiej strony należy pamiętać o związanych z nimi niebezpieczeństwach. $W$ przypadku stosowania technologii informacyjno-komunikacyjnych zadaniem nauczycieli będzie uczulenie uczniów na takie hasła, jak szum informacyjny, informacje śmieciowe, plagiat, oszustwa w sieci, ochrona prywatności, a więc uświadomienie uczniom, na jakie niebezpieczeństwa są narażeni w sieci i jak ich unikać. Ważnym zadaniem szkoły i konkretnych nauczycieli będzie też kształtowanie świadomych, racjonalnych nawyków korzystania z Internetu czy mediów elektronicznych, tak aby uczniowie byli w stanie dokonywać świadomych wyborów i jednocześnie uniknąć uzależnienia od mediów.

Oprócz wspomnianych powyżej innowacji technologicznych, w edukacji językowej pojawiło się również wiele innowacji innego rodzaju, np. związanych z podejściem do nauczania (promowanie autonomii ucznia, trening strategiczny, nauczanie zadaniowe, nauczanie dwujęzyczne, zintegrowane nauczanie przedmiotowo-językowe, podejście leksykalne itp.) czy materiałami do nauczania (np. e-podręczniki). Łączone z nimi doświadczenia pozwalają na lepsze zrozumienie tak założeń teoretycznych, leżących u ich podstaw, jak i problemów związanych z wprowadzaniem samych rozwiązań. 


\section{Nauczyciel wobec działań innowacyjnych}

Jak już zostało wspomniane, nauczyciele to najważniejsi uczestnicy, jeśli nie inicjatorzy, procesów innowacyjnych. Bez ich udziału, aktywnego uczestnictwa nie jest możliwe powodzenie działań innowacyjnych, a co za tym idzie - usprawnienie procesu nauczania/uczenia się języka. Innowacyjny nauczyciel to zarówno inicjator (autor), jak i odbiorca i użytkownik innowacji pedagogicznych. To on przyswaja nowe rozwiązania i wprowadza je do praktyki szkolnej. Często nauczyciel jest jednocześnie innowatorem i nowatorem (por. Zawadzka, 2004: 282). Wprowadzane w szkole innowacje to z reguły substytucja, przekształcenie czy restrukturyzacja lub reorganizacja treści bądź form działania. Co ważne, „innowacje pedagogiczne mogą być różnicowane ze względu na treść, skalę, sposób lub miejsce powstania, a także z uwagi na ich kompleksowość, radykalność czy rodzaj zmiany" (Zawadzka, 2004: 282, za Schulz, 1994: 141). O uznaniu innowacji pedagogicznej za sensowną/celową decyduje przede wszystkim stopień jej przyczyniania się do doskonalenia rzeczywistości dydaktycznej, ale ważne są także jej skutki wychowawcze.

Na powodzenie działań innowacyjnych istotny wpływ mają wiedza nauczycieli, ich pozytywne nastawienie do takich działań, gotowość uczestniczenia oraz warunki, w jakich ma zostać wprowadzona innowacja. Nie bez znaczenia będą też przygotowanie nauczyciela i zdolność do refleksji. Zdaniem Zawadzkiej (2004: 283-284), stosunek nauczycieli do innowacji przejawia się w trzech postawach. Są to:

- postawa zachowawcza

- postawa recepcyjna

- oraz postawa pionierska.

Postawa zachowawcza wiąże się z obawą przed nowinkami, utratą autorytetu czy też z poczuciem zagrożenia, a podejmowane przez nauczyciela/li działania są działaniami o charakterze konformistycznym (np. działania pozorne lub bierność). Postawa recepcyjna charakteryzuje się akceptacją innowacji przy założeniu, że nie niesie ze sobą ryzyka i jest przydatna dla zaspokojenia korzyści własnych nauczyciela. Postawa pionierska wiąże się z gotowością do podejmowania ryzyka związanego z działaniami innowacyjnymi; jest ona typowa dla osób twórczych, kreatywnych, kierujących się interesem grupowym.

Generalnie, nauczyciele bywają nieufni, ponieważ wprowadzanie innowacji często wiąże się z frustracją czy poczuciem zagubienia. Zamiast oczekiwanych korzyści i satysfakcji, pojawiają się zamieszanie i chaos, powodujące reakcje obronne, a nawet wycofanie się. Może się również zdarzyć, że początkowe entuzjastyczne nastawienie ulegnie zmianie z powodu rozczarowań spowodowanych brakiem środków czy wsparcia bądź też negatywną oceną ze 
strony innych nauczycieli lub zwierzchników. Brak koniecznej refleksji powoduje też, że nauczyciele nie myślą o celowości i użyteczności innowacji, ale koncentrują się na nowości i oryginalności pomysłu, o czym pisze m.in. Zawadzka (2004), powołując się na wyniki przeprowadzonych badań.

\section{Innowacyjność a profesjonalizm nauczyciela}

Jak wynika z powyższej dyskusji, w dobie globalizacji innowacyjność jest nieodłączną częścią naszego funkcjonowania nie tylko w edukacji, ale też w życiu codziennym. A zatem, nawiązując do tytułu niniejszego artykułu, należałoby zadać pytanie o zależność między stosunkiem nauczycieli do innowacyjności a ich profesjonalizmem. Czy innowacyjność powinno się traktować jako wyznacznik czy też może jedną z cech profesjonalizmu? Odpowiadając na to pytanie, należałoby najpierw odnieść się do definicji profesjonalizmu, czy też do cech nauczyciela-profesjonalisty („nauczyciela zawodowcy”).

W języku potocznym nauczyciel-profesjonalista to "dobry nauczyciel”. Ur (1997: 3) używa określenia „zawodowiec”, czy też „profesjonalista”, w odniesieniu do osoby, której praca wymaga sprawnego wykonywania określonych zadań; co więcej, członkowie określonej grupy zawodowej (profesjonaliści) posiadają pewne umiejętności i wiedzę wspólne dla nich (tzw. arkana zawodu), które obce sa osobom spoza danego kregu zawodowego, tzn. amatorom. Profesjonaliści starają się też zachować pewne standardy w odniesieniu do posiadanej wiedzy zawodowej, zachowań oraz relacji z „klientami” (tzn. uczniami, w przypadku nauczycieli), a także z innymi zawodowcami (tzn. innymi nauczycielami), co wynika z ich autonomii zawodowej. Ur jest zdania, że jako nauczyciele języków obcych jesteśmy ekspertami, którzy posiadają dogłębną znajomość zasad profesjonalnego działania pozwalajaca na innowacje, ale także na krytyczne odnoszenie się do opinii i rekomendacji ekspertów z innych dziedzin. Nasz profesjonalizm wynika z faktu, że nie tylko nauczamy, ale ciągle się uczymy. Zdobywamy wiedzę przedmiotową, wiedzę o metodach i technikach nauczania i o wielu innych sprawach, co powoduje, że jesteśmy lepiej wykształceni i możemy nauczać coraz efektywniej. "Czytamy, słuchamy, oddajemy się refleksji, dyskutujemy" (Ur, 1997: 5), a połączenie różnych typów wiedzy i doświadczenia pozwala nam podejmować kompetentne/przemyślane decyzje w ściśle określonym kontekście (por. ibidem: 4).

Ur wymienia też cechy nauczyciela-profesjonalisty, wśród których w kontekście innowacyjności na uwagę zasługują następujące:

- nauczyciel myśli, jak usprawnić działania w klasie;

- nauczyciel jest zainteresowany znalezieniem odpowiedzi na pytanie, co się sprawdza w danym kontekście; 
- nauczyciel jest „czynnikiem” wprowadzającym realne zmiany, bądź też pośrednikiem we wprowadzaniu zmian;

- nauczyciel jest oceniany w perspektywie krótkoterminowej w odniesieniu do istoty wprowadzanych przez siebie zmian;

- nauczyciel jest oceniany w perspektywie długoterminowej z punktu widzenia wpływu jego działań na myślenie i działania innych (ibidem). Komorowska i Kiely (1998: 32), odnosząc się do kwalifikacji czy kompetencji nauczycieli języków obcych, niezbędnych z punktu widzenia zachodzących zmian, oprócz tych odnoszących się bezpośrednio do kwalifikacji przedmiotowych wymieniają:

- umiejętności komunikacyjne, obejmujące zarówno komunikację międzyludzką, jak i zarządzanie konfliktem;

- umiejętność współpracy w odniesieniu do stylów zarządzania, strategii stosowanych w klasie czy współdziałania z innymi uczestnikami procesu edukacyjnego;

- kreatywność, przejawiająca się np. niestandardowym (twórczym) podejściem do rozwiązywania problemów, wspieraniem rozwoju ucznia (a nie tylko przekazywaniem wiedzy) czy też promowaniem kreatywności ucznia;

- umiejętności w zakresie posługiwania się technologią informacyjną.

Komorowska (1999) zwraca też uwagę na inne ważne kompetencje nauczyciela, a mianowicie na umiejętność tworzenia własnych programów nauczania (tzw. sylabusy autorskie); świadomy wybór metod i technik nauczania, podręczników i innych materiałów dydaktycznych; wypracowywanie własnych, wewnątrzszkolnych kryteriów oceny uczniów; oraz, co najważniejsze, wykorzystanie samoobserwacii, procesu refleksii oraz badania w działaniu w celu radzenia sobie z problemami oraz przy wprowadzaniu rozwiązań innowacyjnych.

Ustalając listę kompetencji niezbędnych nauczycielowi europejskiemu, aby mógł sprostać wyzwaniom XXI wieku, Schratz (2013: 2) stwierdza, że od nauczycieli należy oczekiwać umiejętności ogólnych, takich jak radzenie sobie z różnorodnością w klasie, praca w zespołach różnego rodzaju, udział w przygotowywaniu programów nauczania czy też stosowanie nowych technologii w codziennej pracy. Dodatkowo Schratz zwraca uwagę na inne umiejętności nauczycieli, od których będzie się oczekiwać zaangażowania w pracę na rzecz różnych grup społecznych, np. w kwestii promowania rozwoju kompetencji umożliwiających członkom społeczeństw zdobywanie wiedzy i uczenie się przez całe życie. Ich zadaniem będzie m.in. wspomaganie jednostek w rozwijaniu kompetencji technologicznych i cyfrowych, pobudzanie kreatywności i innowacyiności oraz umiejętności rozwiązywania problemów czy wreszcie przedsiębiorczości, otwarcia na komunikację międzyludzką oraz tzw. kulturę wizualną (ang. visual culture). 


\section{Wnioski końcowe}

Działania innowacyjne niewątpliwie mają pozytywny wpływ na edukację, przyczyniają się bowiem do poprawy wyników nauczania, a tym samym do wzrostu jakości edukacji. Zmiany w systemie edukacyjnym, polegające na wprowadzaniu „nowych” produktów (programów nauczania, podręczników, metod i środków nauczania), mogą pomóc $w$ lepszym dostosowaniu procesu edukacyjnego do indywidualnych potrzeb ucznia. Dlatego też ważne jest przygotowanie nauczyciela do aktywnego uczestnictwa w takich działaniach.

Podsumowując powyższą dyskusję, można stwierdzić, że „postawa”, czy też kompetencja innowacyjna, nauczyciela - tzn. dostrzeganie potrzeby zmian, otwartość na zmiany, gotowość do ich wprowadzania - leży u podstaw zawodu nauczyciela i powinna znajdować się w centrum zainteresowania osób kształcących przyszłych nauczycieli. Istotne jest uświadomienie sobie znaczenia innowacji jako stałego elementu m.in. rozwoju profesjonalnego i organizacyjnego, zwłaszcza że świat się zmienia, a wraz z nim warunki w naszym najbliższym otoczeniu. Nauczanie języków odniesie znaczne korzyści, jeśli profesjonaliści w tej dziedzinie ustanowią własną tradycję innowacyjnych badań i praktyki (świadomość problemów dotyczących prowadzenia/propagowania takich badań i korzystania z osiągnięć innych dziedzin, zdobywanie doświadczeń w rozwiązywaniu problemów związanych z innowacjami). Uważa się również, że nauczyciele powinni doświadczyć innowacji z pierwszej ręki, jeśli mają akceptować zmiany i wprowadzać je do swojej praktyki pedagogicznej. Tylko przez zapoznanie się z teorią i praktyką innowacji możliwe jest pełne zrozumienie istotnych zagadnień (por. Markee, 1997: 7). Ważne jest też, aby profesjonaliści w dziedzinie nauczania byli bardziej wyczuleni na ewentualny wpływ czynników społeczno-kulturowych, które oddziałują na powodzenie projektów innowacyjnych. Czynniki te mogą się różnić w zależności od kontekstu, ale dostosowanie innowacji do warunków kulturowych oraz kompatybilność z istniejącymi rozwiązaniami (stosowanymi praktykami) mają ogromne znaczenie.

Jak wiadomo, nauczyciele to główni, jeśli nie najważniejsi, aktorzy w procesie wprowadzania nowatorskich zmian (np. programów nauczania) i od ich nastawienia zależeć będzie wprowadzenie zmiany czy powodzenie samej innowacji. Równie ważna, obok pozytywnego nastawienia i przekonania o celowości działań innowacyjnych, będzie chęć zainicjowania i kontynuowania takich działań, a także świadomość faktu, że działania te mają charakter długofalowy (por. Zawadzka 2004; Carless 2013).

Przedstawione w niniejszym artykule refleksje związane z zagadnieniami innowacyjności w edukacji językowej oraz profesjonalizmem nauczyciela można potraktować jako przyczynek do dyskusji na temat kompetencji nauczycieli języków obcych. Z pewnością w dalszym ciągu pozostaje bez odpowiedzi wiele 
pytań dotyczących np. oczekiwań w stosunku do nauczycieli, ich przygotowania do pełnienia różnych funkcji, w tym funkcji innowatora, ich własnych potrzeb w odniesieniu do innowacji dydaktycznych itp.

\section{BIBLIOGRAFIA}

Carless, D. 2013. „Innovation in language teaching and learning”. (w:) The Encyclopedia of Applied Linguistics. (red. C. A. Chapelle). DOI: 10.1002/97 81405198431.wbeal0540.

England, L. 1998. „Promoting effective professional development in English Language Teaching (ELT)". English Teaching Forum, vol. 36, no 2: 18-23. Komorowska, H. 1999. "Successful teaching: How to achieve it, how to assess it". Network, vol. 2, no 2: 3-9.

Komorowska, H. i Kiely, R. 1998. „Quality and impact - the evaluation agenda”. (w:) Innovations and outcomes in English language teacher education. (red. P. J. Melia). The British Council, Poland: The PRINCE Project, s. 15-38. Markee, N. 1997. Managing curricular innovation. New York: Cambridge University Press.

Markee, N. 2001. "The diffusion in innovation in language teaching”. (w:) Innovation in English language teaching. A reader. (red. D. R. Hall i A. Hewings). London: Routledge, s. 118-126.

Schleicher, A. 2016. Educating for innovation and innovation in education. http://oecdeducationtoday.blogspot.com/2016/09/educating-for-inno vation-and-innovation.html.

Schratz, M. 2013. What is a "European teacher"? A discussion paper. European Network on Teacher Education Policies (ENTEP). http://www.see-educoop.net.ed ucation_in/pdf/workshop/tesee/documenti/european-teacher.pdf. DW 05.05.2013.

Schulz, R. 1994. Twórczość pedagogiczna. Warszawa: Instytut Badań Edukacyjnych. Sergeant, S. 2001. "CALL innovation in the ELT curriculum”. (w:) Innovation in English language teaching. A reader. (red. D. R. Hall i A. Hewings). London: Routledge, s. 240-249.

Smak, E. 1997. Z zagadnień innowatyki pedagogicznej. Opole: Wydawnictwo Uniwersytetu Opolskiego.

Ur, P. 1997. „The English teacher as professional”. English Teaching Professional, July, Issue 8: 3-5.

Widdowson, H. G. 2004. "A perspective on recent trends”. (w:) A history of English language teaching. (A. P. R. Howatt i H. G. Widdowson). Oxford: OUP, s. 353-372 (chapter 21).

Zawadzka, E. 2004. Nauczyciele języków obcych w dobie przemian. Kraków: Oficyna Wydawnicza „Impuls”. 